Artikel Penelitian

\title{
Pengaruh Lama Pemaparan Ozon Terhadap Kualitas Mikrobiologi dan Kandungan Nutrisi Susu Kambing Peranakan Ettawa
}

The Effects of Ozone Exposure Time on Microbiological Quality and Nutrient Contents of Ettawa Crossbred Goat Milk

Dian Wahyu Harjanti*, Desy Galuh Kusumaningrum

Departemen Peternakan, Fakultas Peternakan dan Pertanian, Universitas Diponegoro, Semarang

*Korespondensi dengan penulis (harjantidian@gmail.com)

Artikel ini dikirim pada tanggal 19 Februari 2020 dan dinyatakan diterima tanggal 4 September 2020. Artikel ini juga dipublikasi secara online

melalui https://ejournal2.undip.ac.id/index.php/jatp. Hak cipta dilindungi undang-undang. Dilarang diperbanyak untuk tujuan komersial.

Diproduksi oleh Indonesian Food Technologists ${ }^{\circledR}$ @ 2021

\begin{abstract}
Abstrak
Susu kambing mengandung komponen gizi yang tinggi dan dibutuhkan oleh manusia, namun mempunyai sifat mudah rusak akibat cemaran bakteri sehingga dikenal sebagai perishable food. Penelitian ini bertujuan untuk mengaplikasikan ozon dalam susu dengan tujuan untuk menganalisis total bakteri dalam susu, serta pengaruhnya terhadap komponen protein, lemak dan laktosa. Ozon dengan kadar 3 ppm digunakan dalam penelitian ini dan diaplikasikan pada susu dengan lama pemaparan 0, 3, 6, dan 9 menit. Pengamatan dilakukan pada akhir penelitian dan dianalisis dalam hal total bakteri, protein, lemak dan laktosa. Hasil penelitian menunjukkan bahwa jumlah bakteri dalam susu semakin menurun $(p<0,01)$ seiring lamanya waktu pemaparan ozon. Penurunan bakteri mencapai 0,45 ; 0,95; dan 1,42 log CFU/ml masing-masing dengan lama ozonisasi 3, 6 dan 9 menit. Terdapat hubungan yang sangat kuat $\left(r=0,92 ; R^{2}=0,99 ; p<0,0001\right)$ antara lama waktu pemaparan ozon dengan penurunan jumlah bakteri dalam susu yang mengikuti fungsi $y=7 \mathrm{E}+06 \mathrm{e}^{-0,364 x}$. Tingkat lama pemaparan ozon tidak secara nyata mempengaruhi kadar protein susu, namun secara signifikan menyebabkan penurunan pada kadar lemak $(p<0,01)$ dan laktosa susu $(p<0,05)$ pada lama ozonisasi 6 menit. Kesimpulan dari penelitian ini bahwa ozon dapat digunakan untuk meningkatkan kualitas mikrobiologi susu segar dan menjaga kandungan nutrisi susu.
\end{abstract}

Kata kunci: bakteri susu, kandungan nutrisi, ozon, keamanan pangan

\begin{abstract}
Goat milk is known to have high nutritional components that plays an important role in human health. However, it has a short shelf-life and highly perishable. Milk is an excellent medium for the growth of microorganism, particularly bacterial pathogens that cause spoilage and disease in consumers. This research aims to apply ozone in milk, then to analyse bacterial count as well as their effects on protein, fat and lactose. Sample of raw milk were collected before and after ozone gas exposure at 3 ppm for 0, 3, 6 and 9 minutes. The assays were carried out using a randomized experimental design and the results were statistically evaluated by ANOVA. As results, bacterial counts in milk decreased $(p<0.01)$ with the length of ozonation time. The decline in bacterial count reached 0.45; 0.95; and 1.42 $\log \mathrm{CFU} / \mathrm{ml}$ with 3, 6 and 9 minutes ozonation, respectively. There was a very strong relationship $\left(r=0.92 ; R^{2}=0.99\right.$; $p<0.0001)$ between the length of time of ozone exposure and the decrease in the number of bacteria in milk with following equation $y=7 E+06 e^{-0,364 x}$. The duration of ozone exposure did not affect much in milk protein, but significantly caused a decrease in milk fat $(p<0.01)$ and lactose concentrations $(p<0.05)$ at 6 minutes of ozonation. It can be concluded that, ozone could be used to improve the microbiological quality of fresh milk and maintain its nutrient content.
\end{abstract}

Keywords: milk bacteria, nutrient content, ozone, food safety

\section{Pendahuluan}

Susu adalah makanan dengan nilai kandungan gizi dan aktivitas air tinggi, yang menjadi media ideal untuk pertumbuhan mikroorganisme, terutama bakteri sehingga pada akhirnya dapat menyebabkan berkurangnya masa simpan susu dan rendahnya kualitas susu (Harjanti et al., 2020). Jumlah cemaran bakteri yang tinggi, terutama bakteri yang bersifat patogen menjadikan susu tidak layak dan tidak aman untuk dikonsumsi dan tidak aman (Dhanashekar et al., 2012; Harjanti et al., 2018; Puspitarini dan Herbani, 2018). Pada industri pengolahan susu, kandungan bakteri yang tinggi dapat mempengaruhi kualitas dan keamanan produk yang dihasilkan. Susu yang mengandung bakteri dapat menyebarkan penyakit (milk borne disease) (Fagnani et al., 2019; Harjanti et al., 2019). Disisi lain, rendahnya produksi susu sapi perah mengakibatkan tidak tercukupinya kebutuhan protein hewani yang dibutuhkan oleh masyarakat. Oleh karena itu, ternak perah alternatif yang cocok untuk dikembangkan dan dapat diterima oleh masyarakat sebagai penghasil susu adalah daru kambing peranakan ettawa (PE) (Maesya dan Rusdiana, 2018).

Susu kambing memiliki keunggulan yaitu kecernaan yang tinggi, alergenisitas yang rendah dan komposisi kimiawi yang lebih mendekati susu manusia dibandingkan dengan susu sapi (Kumar and Sharma, 2016; Clark and García, 2017; Lad et al., 2017). Diversifikasi olahan susu kambing saat ini sudah bervariasi, seperti yogurt yang membutuhkan bahan 
Tabel 1. Pengaruh lama paparan ozon terhadap kualitas mikrobiologi dan komponen susu

\begin{tabular}{lcccc}
\hline \multirow{2}{*}{ Parameter } & \multirow{2}{*}{ Tanpa ozonisasi } & \multicolumn{3}{c}{ Lama ozonisasi } \\
\cline { 3 - 5 } & & 3 menit & 6 menit & 9 menit \\
\hline Total bakteri (CFU/ml) & $6,75 \times 10^{6 \mathrm{~A}}$ & $2,38 \times 10^{6 \mathrm{~B}}$ & $0,75 \times 10^{6 \mathrm{C}}$ & $0,26 \times 10^{6 \mathrm{D}}$ \\
Total bakteri (Log $\left.{ }_{10} \mathrm{CFU} / \mathrm{ml}\right)$ & 6,83 & 6,38 & 5,88 & 5,41 \\
Kadar lemak (\%) & $3,73^{\mathrm{A}}$ & $3,53^{\mathrm{AB}}$ & $3,42^{\mathrm{B}}$ & $3,38^{\mathrm{C}}$ \\
Kadar laktosa (\%) & $3,97^{\mathrm{a}}$ & $3,89^{\mathrm{ab}}$ & $3,81^{\mathrm{bc}}$ & $3,75^{\mathrm{C}}$ \\
Kadar protein (\%) & 3,21 & 3,15 & 3,02 & 2,99 \\
\hline
\end{tabular}

Keterangan: superskrip lowercase dan uppercase yang berbeda pada baris yang sama, masing-masing menunjukkan adanya perbedaan yang nyata $(p<0,05)$ dan $(p, 0,01)$.

baku susu kambing dengan kualitas baik yaitu cemaran bakteri rendah dan kandungan protein serta lemak yang tinggi (Prayitno et al., 2020).

Pemanasan merupakan cara yang umum dilakukan untuk membunuh bakteri perusak dan patogen dalam susu sehingga dihasilkan susu yang aman untuk dikonsumsi. Teknik pasteurisasi yang dilaporkan oleh Ibrahim et al. (2020) yaitu $85^{\circ} \mathrm{C}$ selama 5 detik, mampu menurunkan jumlah bakteri dalam susu (Ibrahim et al., 2020). Namun demikian, proses pemanasan (pasteurisasi dan sterilisasi) tidak hanya membunuh bakteri berbahaya namun juga mengakibatkan perubahan rasa, adanya cooked flavor dan flat flavor serta kehilangan sebagian kandungan nutrisi seperti vitamin dan protein (Zabbia et al., 2012; Manzi et al., 2013). Oleh karena itu, diperlukan suatu cara pengawetan pangan yang dapat menginaktivasi bakteri perusak maupun patogen namun memberikan pengaruh minimal terhadap penurunan kualitas dan nutrisi susu. Teknologi ozon diketahui memiliki kekuatan oksidasi yang mampu membunuh bakteri (Fontes et al., 2012; Cavalcante et al., 2013; Varga and Szigeti (2016). Gas ozon telah tersertifikasi oleh The Environment Protection Agency (EPA) sebagai sanitizer untuk makanan dan telah mendapatkan izin untuk diaplikasikan secara langsung pada produk pangan oleh Food and Drug Administration (FDA) (Moore et al., 2000). Gas ozon juga telah tersertifikasi dan diizinkan untuk digunakan pada proses pengolahan pangan (Selma et al., 2008).

Penelitian ini bertujuan untuk menggunakan ozon pada susu kambing dan menganalisis bakteri pada susu kambing PE serta untuk menganalisis perubahan kualitas yang diakibatkan dari metode tersebut. Manfaat yang diperoleh dari penelitian ini adalah sebagai upaya untuk menemukan cara pengawetan susu dengan menggunakan ozon.

\section{Materi dan Metode}

Penelitian ini dilakukan dari bulan Juli hingga November 2019. Susu kambing segar diperoleh dari 8 ekor kambing Peranakan Ettawa laktasi (yang diperoleh dari campus farm) pada pemerahan pagi, kemudian langsung dihomogenkan dan dilakukan perlakuan dengan ozon tanpa melalui tahap penyimpanan. Peralatan yang digunakan meliputi ozon generator yang dilengkapi outlet dengan porous plate dengan kadar ozon 3 ppm. Susu sebanyak 1 liter ditempatkan ke dalam kontainer steril dan diaduk dengan kecepatan $20 \mathrm{rpm}$. Teknik ini mengacu pada Cavalcante et al. (2013). Paparan ozon yang diterapkan tersebut dilakukan dengan variasi waktu sebagai perlakuan. Susu kemudian diambil pada menit ke 3,6 , dan 9 setelah paparan ozon. Pengambilan sampel susu dilakukan secara aseptik. Proses tersebut dilakukan secara triplicate.

Pengujian Jumlah Bakteri dan Kandungan Nutrisi

Prosedur perhitungan total bakteri dilakukan dengan metode total plate count berdasarkan prosedur pada SNI 2897:2008 dengan inkubasi dilakukan pada suhu $37{ }^{\circ} \mathrm{C}$ selama 24 jam. Analisis kandungan nutrisi susu (lemak, protein dan laktosa) dilakukan menggunakan Lactoscan Milk Analyzer (MCC, Bulgaria).

\section{Analisis Data}

Data diperoleh dari 4 kali ulangan dan disajikan dalam bentuk rata-rata \pm standar deviasi untuk setiap parameter uji, baik dengan perlakuan tanpa ozonisasi (kontrol) maupun dengan ozonisasi selama 3, 6 dan 9 menit. Data yang diperoleh selanjutnya dianalisis dengan Rancangan Acak Lengkap berdasarkan Steel and Torrie (1991).

\section{Hasil dan Pembahasan}

\section{Kualitas Mikrobiologi Susu Kambing}

Hasil yang diperoleh menunjukkan bahwa lama waktu ozonisasi memberikan pengaruh sangat nyata $(p<0,01)$ terhadap total bakteri susu kambing PE (Tabel 1). Total bakteri susu pada kelompok yang mendapatkan perlakuan ozonisasi jauh lebih rendah dibandingkan dengan kontrol (tanpa perlakuan ozon). Susu kambing PE sebelum mendapatkan perlakuan ozon memiliki kandungan bakteri yang sangat tinggi, yaitu 6,75 $\times 10^{6}$ $\mathrm{CFU} / \mathrm{ml}$ melebihi standar kualitas susu segar berdasarkan SNI 3141:2011, yaitu maksimal $1 \times 10^{6}$ $\mathrm{CFU} / \mathrm{ml}$. Semakin lama waktu ozonisasi, jumlah cemaran bakteri dalam susu semakin menurun $(p<0,05)$, dengan jumlah bakteri terendah terdapat pada lama ozonisasi 9 menit, yaitu $0,26 \times 10^{6} \mathrm{CFU} / \mathrm{ml}$. Jumlah bakteri dalam susu yang mendapatkan paparan ozon 6 menit $\left(0,75 \times 10^{6} \mathrm{CFU} / \mathrm{ml}\right)$ juga telah berada dalam standar kualitas SNI. Namun susu yang mendapat paparan ozon 3 menit masih memiliki kandungan bakteri yang tinggi yaitu $2,38 \times 10^{6} \mathrm{CFU} / \mathrm{ml}$, sehingga masih dikategorikan tidak layak dan tidak aman untuk dikonsumsi langsung.

Persen penurunan jumlah cemaran bakteri tertinggi terdapat pada susu yang mendapat paparan ozon paling lama yaitu 9 menit sebesar $96,14 \%$, sedangkan pada ozonisasi 3 dan 6 menit dapat dilihat bahwa persen penurunan masing-masing mencapai $64,84 \%$ dan $88,89 \%$ (data diolah). Ozon mampu 
menghancurkan mikroorganisme melalui oksidasi progresif komponen seluler yang vital (Khadre et al., 2001; Fontes et al., 2012). Dinding sel bakteri adalah target pertama ozonisasi, dengan oksidasi asam lemak tak jenuh ganda dan akibat hilangnya permeabilitas selektif yang pada akhirnya dapat mengganggu kinerja sel bakteri (Cavalcante et al., 2013). Selain itu, ozon juga menyebabkan oksidasi gugus sulfhidril dan asam amino dari enzim peptida dan protein, termasuk asam nukleat (Khadre et al. 2001; Moore et al., 2000). Pada saat terjadi kontak antara ozon dengan bakteri, dapat terbentuk komplek phospholipid dan lipoprotein pada struktur bakteri sebagai akibat dari lepasnya satu molekul oksigen dan oksidasi dari membran bakteri. Selanjutnya atom oksigen lainnya yang berada dalam membran bakteri dapat berubah menjadi gas oksigen (Lobo et al., 2010; Novak et al., 2004).

Pada bakteri yang membentuk spora, ozon mampu mendegradasi lapisan kulit spora sehingga mampu mangganggu metabolisme bagian korteks dan inti spora (Fontes et al., 2012; Amorim et al., 2013). Penelitian Cavalcante et al. (2013) menggunakan susu sapi dengan kadar ozon 1,5 mg/l (setara dengan 1,5 ppm) dengan waktu ozonisasi selama 5 menit tidak cukup untuk menginaktivasi bakteri secara signifikan. Pada kadar ozon 1,5 ppm tersebut, dengan lama ozonisasi yang diperpanjang yaitu selama 10 menit mampu mengurangi jumlah bakteri lebih tinggi, yaitu Enterobacteriaceae yang menurun sebesar $0,58 \log _{10}$; Staphylococcus sp menurun $0,52 \log _{10}$ dan fungi yang menurun sebesar $0,25 \log _{10}$. Berdasarkan pengolahan data Tabel 1, dengan kadar ozon yang lebih tinggi yaitu 3 ppm, penurunan bakteri dapat dicapai sebanyak 0,45 ; 0,95; dan $1,42 \log _{10}$ dengan lama ozonisasi yang lebih singkat yaitu 3, 6 dan 9 menit. Penelitian lainnya dengan konsentrasi ozon yang lebih tinggi digunakan oleh Brodowska et al. (2018), yaitu sebesar 5-35 ppm selama 5-25 menit, menghasilkan penurunan jumlah bakteri mencapai $99 \%$. Jika dibandingkan dengan penelitian ini, persen penurunan bakteri yang tidak jauh berbeda dapat dicapai pada kelompok yang mendapat paparan ozon selama 9 menit, yaitu sebesar 96,14\% dengan kadar ozon yang lebih rendah yaitu $3 \mathrm{ppm}$. Berdasarkan analisis regresi sebagaimana tampil pada Figur 1, diketahui bahwa terdapat hubungan non-linier nyata dengan keeratan yang kuat antara jumlah bakteri dan lama ozonisasi ( $\left.p<0,0001 ; r=0,92 ; R^{2}=0,9938\right)$, yang menunjukkan bahwa semakin lama waktu ozonisasi maka jumlah bakteri dalam susu dapat semakin menurun. Beberapa publikasi terdahulu telah banyak mengulas mengenai aspek keamanan penggunaan ozon bagi manusia. Ozon diketahui dapat terdegradasi dalam oksigen, tanpa menghasilkan produk atau limbah beracun, sehingga teknologi preservasi pangan menggunakan ozon aman untuk diterapkan untuk semua jenis makanan (Cavalcante et al., 2013; Brodowska et al., 2018).

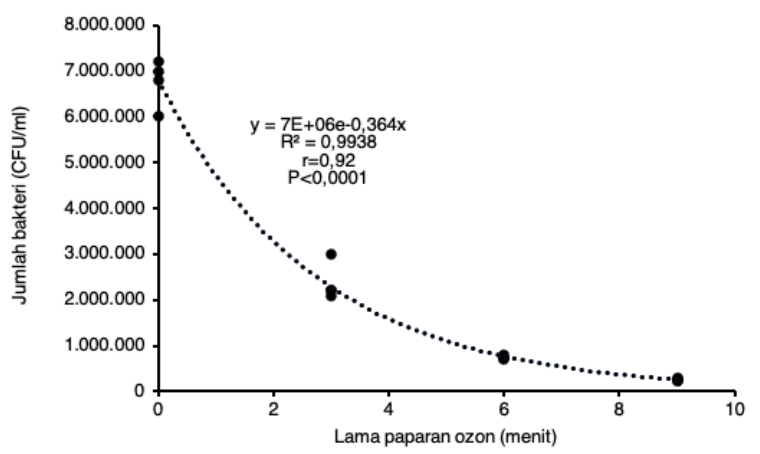

Figur 1. Hubungan antara lama waktu pemaparan ozon terhadap jumlah bakteri susu kambing

\section{Pengaruh Ozonisasi terhadap Kandungan Nutrisi}

Berdasarkan data Tabel 1, semakin lama waktu ozonisasi menyebabkan semakin menurunnya kadar lemak secara signifikan $(p<0,01)$. Perlakuan ozonisasi selama 9 menit menyebabkan penurunan kadar lemak sangat nyata dibandingkan dengan perlakuan ozonisasi selama 6 menit dan kontrol. Namun, ozonisasi selama 3 menit tidak memberikan pengaruh signifikan terhadap kadar lemak susu kambing. Kadar lemak susu pada semua kelompok perlakuan, masih berada diatas standar kualitas yang ditetapkan oleh SNI, yaitu minimal $3 \%$.

Evaluasi terhadap kandungan nutrisi susu setelah aplikasi ozon mengindikasikan bahwa ozon dapat mempengaruhi sifat kimiawi dan organoleptik susu. Produksi mentega dengan teknologi ozon mempunyai kelebihan dalam membunuh mikroba namun menurunkan kestabilan oksidatif pada produk (Sert et al., 2020). Dampak ozon terhadap lemak diduga disebabkan oleh oksidasi lipid (Kim et al., 1999; Calvante et al., 2013). Penurunan kadar lemak pada penelitian ini diduga karena lemak berinteraksi dengan fraksi-fraksi lain saat proses ozonisasi. Lemak bersifat hidrofobik, sehingga pada saat sirkulasi terjadi semacam pengadukan yang menyebabkan fraksi lemak dapat terpisah dari air (Hwang et al., 2007). Semakin tinggi frekuensi sirkulasi menyebabkan kontak antara fraksi lemak dan fraksi non lemak juga semakin tinggi, yang mengakibatkan semakin banyak jumlah lemak yang terikat oleh fraksi non lemak (Torlak and Sert, 2013; Varga and Szigeti, 2016). Globula lemak yang terdispersi terselubungi protein, dimana bagian non polar protein terikat pada bagian luar glubola lemak, sedangkan bagian polar protein terikat ke air (Torlak and Sert, 2013). Pada laktosa susu, ozonisasi selama 3 dan 6 menit tidak mempengaruhi kadar laktosa secara signifikan. Namun terjadi penurunan kadar laktosa secara signifikan pada lama ozonisasi 9 menit. Meskipun demikian, kadar laktosa susu pada semua kelompok perlakuan yaitu pada lama ozonisasi 3, 6 dan 9 menit masih sesuai dengan standar mutu susu menurut SNI, yaitu minimal 3\%. Hasil yang berbeda dilaporkan oleh Calvante et al. (2013) yang menyatakan bahwa penggunaan ozon 1,5 ppm sampai dengan 15 menit tidak merubah kandungan lemak dan laktosa susu. Namun demikian, efektifitas sterilisasi terhadap bakteri pada penelitian tersebut lebih rendah dibandingkan 
dengan penelitian ini karena membutuhkan waktu yang lebih lama dan tingkat penurunan bakteri lebih rendah.

Aplikasi ozon pada penelitian ini tidak memberikan pengaruh nyata terhadap kadar protein susu. Hal tersebut dikarenakan ozonisasi merupakan proses sterilisasi tanpa menggunakan suhu yang tinggi sehingga kerusakan terhadap kandungan protein dapat diminimalisasi (Uzun et al., 2012; Dissanayake and Vasiljevic, 2009; Lad et al., 2017). Penelitian sebelumnya yang menggunakan isolat whey protein dengan diberi perlakuan ozon dilaporkan mampu meningkatkan foaming capacity dan foam stability dari protein (Uzun et al., 2012; Segat et al., 2014), yang menandakan adanya perbaikan kualitas setelah perlakuan ozon. Penelitian tersebut sekaligus dapat membuktikan bahwa ozon sangat mungkin dikembangkan dalam industri pangan. Hasil evaluasi terhadap lemak, laktosa dan protein susu pada penelitian ini menunculkan dugaan baru bahwa proses ozonisasi mungkin mempengaruhi senyawa karbon pada susu, sedangkan pada senyawa nitrogen pengaruhnya tidak signifikan. Penelitian lebih lanjut diperlukan untuk dapat menjawab dugaan tersebut.

\section{Kesimpulan}

Perlakuan ozon memberikan dampak yang spesifik pada total bakteri, protein, lemak dan laktosa pada susu kambing PE. Perlakuan susu kambing PE dengan ozon pada konsentrasi 3 ppm dan lama proses ozonisasi 6 menit, dapat digunakan untuk meningkatkan kualitas mikrobiologi susu segar dan juga menjaga kandungan nutrisi susu.

\section{Daftar Pustaka}

Amorim, E.O.C., Tribst, A.A.L., Augusto, P.E.D., Cristianini, M. 2013. Inactivation of $E$. coli and $B$. subtilis spores in ozonized cassava starch. Food Science and Technology 33(2):289-294. DOI:10.1590/S0101-20612013005000043.

Brodowska, A.J., Nowak, A., Šmigielski, K. 2018. Ozone in the food industry: Principles of ozone treatment, mechanisms of action, and applications: An overview. Critical Reviews in Food Science and Nutrition 58(13):2176-2201. DOI:10.1080/ 10408398.2017.1308313.

Cavalcante, D.A., Júnior Leite, B.R.C., Tribst, A.A.L., Cristianini, M. 2013. Improvement of the raw milk microbiology quality by ozone treatment. International Food Research Journal 20(4):20172021. DOI:10.1111/1471-0307.12302

Clark, S., García, M.B.M. 2017. A 100-Year Review: Advances in goat milk research. Journal of Dairy Science 100:10026-10044. DOI:10.3168/ jds.2017-13287.

Dhanashekar, R., Akkinepalli, S., Nellutla, A. 2012. Milkborne infections: An analysis of their potential effect on the milk industry. Germs 2(3):101-109. DOI:10.11599/germs.2012.1020.

Dissanayake M., Vasiljevic T. 2009. Functional properties of whey proteins affected by heat treatment and hydrodynamic high-pressure shearing. Journal of Dairy Science 92 (4):13871397. DOI:10.3168/jds.2008-1791.

Fagnani, R., Eleodoro, J.I., Zanon, E.O. 2019. Milkborne infections awareness and the health status of consumers: An on-line survey. International Dairy Journal 96:85-92. DOI:10.1016/ j.idairyj.2019.04.013.

Fontes, B., Heimbecker, A.M.C., Brito, G.D.S., Costa, S.F., van der Heijden, M., Levin, A.S., Rasslan, S. 2012. Effects of low-dose gaseous ozone on pathogenic bacteria. Infectious Diseases 12(358):1-6. DOI:10.1186/1471-2334-12-358.

Harjanti, D.W., Ciptaningtyas, R., Wahyono, F., Setiatin, E.T. 2018. Isolation and identification of bacterial pathogen from mastitis milk in Central Java Indonesia. IOP Conf. Series:Earth and Environmental Science 102:012076. DOI:10.1088/1755-1315/102/1/012076.

Harjanti, D.W., Wahyono, F., Afifah, D.N. 2019. Milk production and milk quality of sub-clinical mastitis cows feed with different supplementation of herbal diet. IOP Conf. Series:Earth and Environmental Science 205:012062 DOI:10.1088/17551315/250/1/012062 .

Harjanti, D.W., Wulandari, D., Hartanto, R., Muktiani, A. 2020. Tingkat peradangan mammary dan stabilitas susu sapi mastitis subklinis yang mendapat suplemen herbal $\mathrm{Zn}$-Se proteinat. Livestock and Animal Research 18(2): 115-125. DOI:10.20961/lar.v18i2.42935.

Hwang, S.J., Lee, H.S., Park, S.G., Kwak, H.S. 2007. Comparison of physicochemical and sensory properties of freeze-concentrated milk with evaporated milk during storing. AsianAustralasian Journal of Animal Science 20(2):273282. DOI:10.5713/ajas.2007.273.

Ibrahim, A.I., Naufalin, R., Wuryatno, E., Dwiyanti, H., Hamouda, S.E. 2020. Influence of temperature and time on microbial. Physicochemical and functional quality of goat milk. African Journal of Food Science 14(4):86-91. DOI:10.5897/ AJFS2020.1912.

Khadre, M.A., Yousef, A.E., Kim, J.G. 2001. Microbiological aspects of ozone applications in food: a review. Journal of Food Science. Chicago 66(9):1242-1252. DOI:10.1111/j.1365-2621.2001. tb15196.x.

Kim, J.G., Yousef, A.E., Dave, S. 1999. Application of ozone for enhancing the microbiological safety and quality of food: A review. Journal of Food Protection 62(9):1071-1087. DOI:10.4315/0362028X-62.9.1071.

Kumar, A., Sharma, A. 2016. Nutritional and medicinal superiority of goat milk over cow milk in infants. International Journal of Pediatric Nursing 2(1):4650. DOI:10.21088/ijpen.2454.9126.2116.6.

Lad, S.S., Aparnathi, K.D., Mehta, B., Velpula, S. 2017. Goat milk in human nutrition and health- $A$ Review. International Journal of Current Microbiology and Applied Science 6(5):17811792. DOI:10.20546/ijcmas.2017.605.194. 
Lobo, V., Patil, A., Phatak, A., Chandra, N. 2010. Free radicals, antioxidants and functional foods: Impact on human health. Pharmacognosy Reviews 4(8):118-126. DOI:10.4103/0973-7847.70902.

Maesya, A., Rusdiana, S. 2018. Prospek pengembangan usaha ternak kambing dan memacu peningkatan ekonomi peternak. Jurnal Sosial Ekonomi dan Kebijakan Pertanian 7(2):114. DOI:10.21107/agriekonomika.v7i2.4459.

Manzi, P., M.G.D., Constanzo, M., Mattera. 2013. Updating nutritional data and evaluation of technological parameters of Italian milk. Foods 2(1): 254-273. DOI:10.3390/foods2020254.

Moore, G., Griffith, C., Peters, A. 2000. Bactericidal properties of ozone and its potential application as a terminal disinfectant. Journal of Food Protection 63(8):1100-1106. DOI:10.4315/0362-028X-63. 8.1100 .

Novak, J.S., Yuan, J.T.C. 2004. Increased inactivation of ozone-treated Clostridium perfringens vegetative cells and spores on fabricated beef surfaces using mild heat. Journal of Food Protection 67(2): 342346. DOI:10.4315/0362-028X-67.2.342.

Prayitno, S.S., Sumarmono, J., Rahardjo, A.H.D., Setyawardani, T. 2020. Modifikasi sifat fisik yogurt susu kambing dengan penambahan microbial transglutaminase dan sumber protein eksternal. Jurnal Aplikasi Teknologi Pangan 9(2):77-82. DOI:10.17728/jatp.6396.

Puspitarini, O.R., Herbani, M. 2018. Kadar protein, kadar lemak dan solid non-fat susu kambing pasteurisasi pada penyompanan refrigerator. Jurnal Aplikasi Teknologi Pangan 7(1):12-14. DOI:10.17728/jatp.2162.

Segat, A.M., Biasutti, L., Lacumin, G., Comi, F., Baruzzi, C., Carboni, N., Innocente. 2014. Use of ozone in production chain of high moisture Mozarella cheese. Food Science and Technology 55:513520. DOI:10.1016/j.Iwt.2013.10.029.
Selma, M.V., Ibanez, A.M., Cantwell, M., Suslow, T. 2008. Reduction by gaseous ozone of Salmonella and microbial flora associated with fresh-cut cantaloupe. Food Microbiology 25(4):558-565. DOI:10.1016/j.fm.2008.02.006.

Sert, D., Mercan, E., Kara, U. 2020. Butter production from ozone-treated cream: Effects on characteristics of physicochemical, microbiological, thermal and oxidative stability. DOI:10.1016/j.Iwt.2020.109722.

SNI 2897:2008. Standar Nasional Indonesia: Metode pengujian cemaran mikroba dalam daging, telur dan susu, serta hasil olahannya. Badan Standardisasi Nasional.

Steel, R.G.D., Torrie, J.H. 1991. Prinsip dan Prosedur. PT. Gramedia, Jakarta. (Diterjemahkan oleh Bambang Sumantri).

Torlak, E., Sert, D. 2013. Inactivation of Cronobacter by gaseous ozone in milk powders with different fat contents. International Dairy Journal 32(1):121125. DOI:10.1016/j.idairyj.2013.05.013.

Uzun, H., Ibanoglu, E., Catal, H., Ibanoglu, S. 2012. Effects of ozone on functional properties of proteins. Food Chemistry 134(2):647-654. DOI:10.1016/j.foodchem.2012.02.146.

Varga, L., Szigeti, J. 2016. Use of ozone in dairy industry: A Review. International Journal of Dairy Technology 69(2):157-168. DOI:10.1111/14710307.12302.

Zabbia, A., DeKock, R., Buys, E. 2012. Undesirable Sulphur and carbonyl flavor compounds in UHT milk: A Review. Critical Reviews in Food Science and Nutrition 52(1):21-30. DOI:10.1080/ 10408398.2010 .487166 . 